\title{
INFLUENCE OF PRODUCT SPECIFICATIONS AND PRICES ON THE LAPTOP PURCHASE DECISION HEWLETT PACKARD (HP) BRAND (Case Study on Pegasus Computer Store Customers Tebing Tinggi)
}

\author{
Abednego Ketaren \\ STIE Bina Karya, Tebing Tinggi
}

\begin{abstract}
This study aims to determine the effect of product specifications and prices on purchasing decisions for Hewlett Packard brand laptops (a case study on a Pegasus computer store customer at Cliff High). The independent variables of this study consist of product specifications and prices, while the dependent variable is purchasing decisions. The research was conducted on the customers of Pegasus Computer Tebing Tinggi shop. Data were analyzed using multiple linear regression analysis method. The results of this study show. (1) Product specifications have an effect on purchasing decisions, (2) price has no significant effect on purchasing decisions, (3) product specifications and prices have no simultaneous effect on purchasing decisions.
\end{abstract}

\section{Keywords: Product specification, Price, Purchase Decision}

\section{INTRODUCTION}

The development of communication media in Indonesia is very fast. The era of globalization which is being discussed by many people lately has also had an effect on the development of telecommunications technology. This can be seen in the last 10 years. In 10 years ago people could only communicate long distances via landline telephones, but now there are communication tools that can be taken wherever we go and are more practical to use.

One of the difficulties faced by companies to achieve success in marketing a product is not only selling or exchanging it for something, but the most important thing is how to meet consumer wants and needs so as to create satisfaction, both from the consumer and producer side. Laptop manufacturers provide everything that is needed by consumers, thereby influencing consumer behavior in making purchases. Due to the large number of laptop manufacturers, it is possible that there is very tight competition among laptop manufacturers to be able to win the competition by relying on technological advantages, quality, and trying to create new innovations that are popular with consumers.

A product is anything that can be offered to a market for attention, purchase, use, or consumption and that can satisfy a want or need. In a broad definition, the product includes a physical object, person, place, organization, idea, or mix of all these forms.

Decision making is a basic psychological process that plays an important role in understanding how consumers actually make purchasing decisions. The decision-making process begins with a need that is trying to be fulfilled. Fulfillment of this need is related to several alternatives so it is necessary to conduct an evaluation aimed at obtaining the best alternative from consumer perceptions. In this comparison process, consumers need information whose amount and level of importance depend on the needs of consumers and the situation they face. Purchasing decisions will be made using the rule of balancing the positive side with the negative side of a brand (compensatory decision rule) or finding the best solution from the consumer's perspective (non-compensatory decision rule). 


\section{INFLUENCE OF PRODUCT SPECIFICATIONS AND PRICES ON THE LAPTOP PURCHASE DECISION HEWLETT PACKARD (HP) BRAND \\ (Case Study on Pegasus Computer Store Customers Tebing Tinggi)}

DOI: https://doi.org/10.54443/ijset.v1i3.16

Product specifications are in the form of details or descriptions of an item/service. Product planning needs to think about products and services on three levels. The most basic level is the core product (core product), the core product consists of the core benefits for solving problems that consumers seek when they buy a product or service. In designing the product, the marketer must first define the benefits that the product will provide to the consumer. Furthermore, product planning must create an actual product around the core product. The actual product may have five characteristics: quality level, features, design, brand name, and packaging. Finally, product planning must embody additional products around the core product and the actual product by offering additional services and benefits to consumers.

Price is a value that must be issued by the buyer to get goods or services that have a use value and their services, prices are flexible, which can be adjusted. Before setting the price, the company must know the purpose of the pricing itself, if the goal is clear, then the pricing can be done easily.

Price is a monetary unit or other measure (including goods and services) that are exchanged in order to obtain ownership rights or use of an item or service, Tjiptono (2008: 156). And price is the only element of the marketing mix element that provides income or income for the company compared to other marketing mix elements (product, promotion and distribution).

Understanding consumer behavior is absolutely necessary, but it is not easy and very complex. The complexity of consumer behavior is caused by the existence of unlimited consumer needs, as well as the many factors that are considered and have a tendency to interact with each other. By understanding consumer behavior, companies can find out what factors are considered by consumers in consuming a product.

In consuming a product, consumers usually consider in terms of the product and the price offered by the company. Consumers consider products usually in terms of shape, design, features of the product, and the durability of the product. In reality, consumers in buying a product consider the price of the product which is adjusted to the quality and reliability of the product. We can no longer make technological progress as a complementary thing, because almost all human activities really need technological assistance, such as work in offices and administration that really need the help of a computer or laptop, as well as academic activities and the teaching and learning process. Teacher,

Currently the condition of laptop competition is very tight, so companies must make strategies to achieve a higher market share. Laptops are one of the suggestions for meeting consumer needs in the field of information technology. Following up on this, the author intends to conduct a more in-depth study of the factors that influence consumer purchasing decisions for laptop products into a thesis research entitled "INFLUENCE OF PRODUCT SPECIFICATIONS AND PRICES ON THE PURCHASE DECISION OF THE HEWLETT PACKARD BRAND LAPTOP (Case Study on Pegasus Computer Store Customers Tebing Tinggi)".

\subsection{Formulation of the problem}

Based on the background above, the formulation of the problem can be formulated as follows: (1) Do product specifications affect the purchasing decision of Hewlett Packard laptop products? (2) Does price affect the purchase decision of Hewlett Packard laptop products? (3) Do 


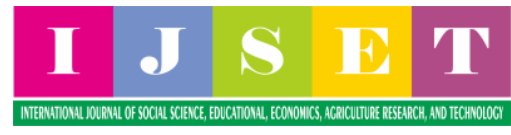

product specifications and prices have an effect on purchasing decisions for Hewlett Packard laptop products?

\subsection{Research purposes}

The objectives of this study are as follows: (1) To determine the effect of product specifications on purchasing decisions for Hewlett Packard brand laptops. (2) To determine the effect of price on the decision to purchase a Hewlett Packard brand laptop. (3) To determine the effect of product specifications and prices on purchasing decisions of Hewlett Packard brand laptops.

\section{THEORY BASIS}

\subsection{Products}

A product is anything that can be offered to a market to meet consumer wants or needs (Kotler, 2008: 266). According to Basu Swastha and Irawan (2010: 165), the definition of a product is as follows: "Product is a complex nature that can be touched or cannot be touched, including packaging, color, price, company and retailer's prestige, company and retailer services, which accepted by the buyer to satisfy his wants or needs".

The definition above can be concluded that the product is everything that is offered by a person or company that has benefits in the form of tangible objects or abstract objects that are intangible, whose purpose is to satisfy consumer wants and needs.

According to Kotler (2008: 269) in developing a product and service marketing strategy the development of several product classifications. Marketing usually classifies products based on various product characteristics such as:

a. According to their nature, among others:

1) Durable goods(durable goods) are tangible goods that can usually be used for a relatively long time. Example: Mobile

2) Non-durable goods(non-durable goods) are tangible goods that are usually consumed by one or more users. For example: toothpaste, bath soap, and others.

3) Services are activities of any service offered by producers or companies to their consumers, such as travel services and motorbike repair shops.

b. Based on the purpose of the purchase, among others:

1) Consumer products, namely products or goods purchased or leased by consumers for their personal interests.

2) Industrial products, namely products or goods that are rented or purchased by consumers, both individuals and organizations to be used in the production process further in other business processes.

\subsection{Price}

Pricing is actually quite complex and difficult. That the complexity and importance of pricing requires a systematic approach, which involves setting goals and developing a pricing structure further.

According to Basu Swastha (2010: 147) means that "price is the amount of money (plus some goods if possible) needed to add a number of combinations of goods and services".

According to Alma (2014:169) suggests that: price is the value of an item expressed in money.

Based on the opinions of the experts above, it is concluded that price is a value (usually expressed in money) that must be sacrificed to be able to own, use or consume goods and services 


\section{INFLUENCE OF PRODUCT SPECIFICATIONS AND PRICES ON THE LAPTOP PURCHASE DECISION HEWLETT PACKARD (HP) BRAND \\ (Case Study on Pegasus Computer Store Customers Tebing Tinggi) \\ DOI: https://doi.org/10.54443/ijset.v1i3.16}

in order to get satisfaction. So it can be concluded that if the price is very high, consumers usually expect high quality, and their actual perception will be influenced by this expectation. If the price is too high, the organization is seen as not caring about the customer, or is considered a fraud. On the other hand, if the price is too low, customers may doubt the organization's ability to service quality. The price indicators according to Mursid (2014: 83 - 84) are as follows:

a. Competitive prices, namely the prices offered are more competitive than competitors.

b. Price compatibility with market prices, namely price conformity with the market.

c. Price compatibility with product quality, namely the price offered is in accordance with the quality of the price.

d. Installments are payments that can be paid in installments over a certain period of time.

\subsection{Purchase Decision}

The buying decision-making process is strongly influenced by consumer behavior. The process is actually a problem solving process in order to meet consumer wants or needs.

According to Sangadji et al (2013: 120) defines a decision as the selection of an action from two or more alternative choices.

Schiffman et al (2008: 485), a decision is a selection of two or more alternative choices. In other words, alternative options must be available to a person when making a decision.

According to Abdullah and Francis Tantri (2013: 112-123), the main factors that influence buying behavior are as follows:

a. Cultural Factor

Cultural factors have the broadest and deepest influence on consumer behavior. These cultural factors consist of: Culture, Subculture, Social Class

b. Social Factor

The behavior of a consumer is also influenced by social factors such as reference groups (reference groups), family, and social roles and status.

c. Personal Factor

A buyer's decision is also influenced by personal characteristics, namely the age of the buyer at the stage of the life cycle, occupation, economic conditions, and lifestyle.

d. Psychological Factors

A person's purchase choice is influenced by four main psychological factors-motivation, perception, knowledge (learning), and attitude beliefs.

\subsection{Conceptual Framework}

This study examines the effect of product specifications and prices on purchasing decisions. The conceptual framework of the research can be described as follows: 

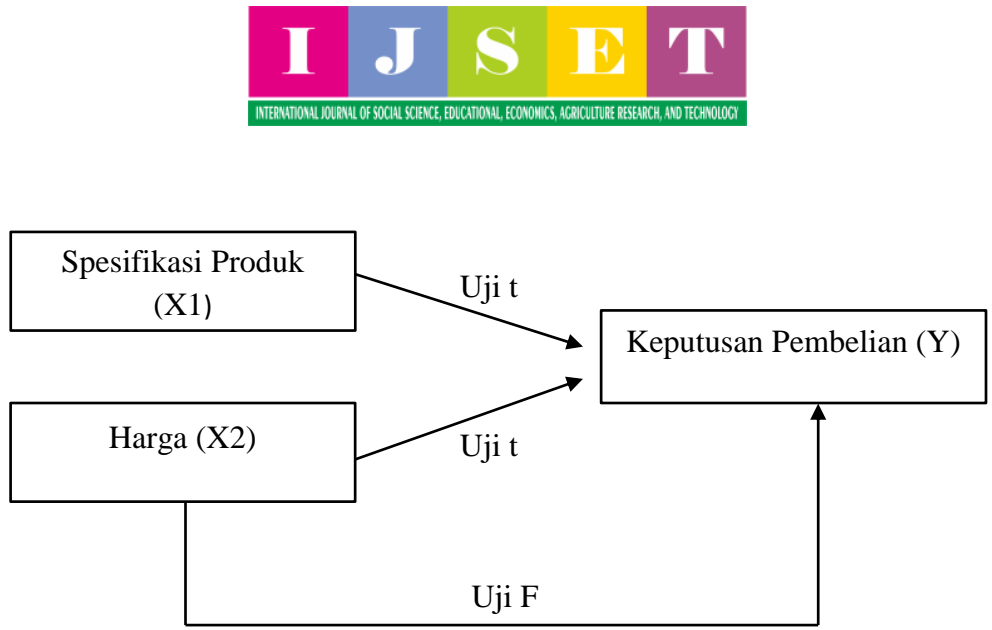

Image 1 Conceptual Framework

\subsection{Hypothesis}

Based on the conceptual framework above, the hypotheses in this study are: (1) Product specifications have an effect on purchasing decisions for Hewlett Packard laptop products. (2) Price has an effect on purchasing decisions for Hewlett Packard laptop products. (3) Product specifications and prices have an effect on purchasing decisions for Hewlett Packard laptop products.

\section{RESEARCH METHOD}

\subsection{Posulation and Sample}

The population is the entire research subject. If someone wants to examine all the elements that exist in the research area, then the research is a population study. The population included in this study is through consumers who have used and purchased Hewlett Packard laptop products at the Pegasus Tebing Tinggi Computer Store based on the data for the last 5 months as many as 50 customers.

The sampling technique referred to in this study is Accidental Sampling, namely customers who when the researchers surveyed the field at the Pegasus Computer Store to meet the quota of 50 people.

\subsection{Types and Sources of Data}

This research is all sourced from primary data. Primary data in this study is data obtained directly from the distribution of a list of statements or questionnaires to respondents who were selected for this study. The data needed in this study were the identity data of the respondents, namely name, gender, age, occupation and data on respondents' perceptions of the decision to purchase a Hewlett Packard brand laptop.

\subsection{Variable Operational Definition}

The operational definition of variables can be seen in table 1 below: 
INFLUENCE OF PRODUCT SPECIFICATIONS AND PRICES ON THE LAPTOP PURCHASE DECISION HEWLETT PACKARD (HP) BRAND

(Case Study on Pegasus Computer Store Customers Tebing Tinggi)

DOI: https://doi.org/10.54443/ijset.v1i3.16

Table 1 Variable Operational Definition Table

\begin{tabular}{|c|c|l|l|l|}
\hline No & Variable & \multicolumn{1}{|c|}{ Definition } & \multicolumn{1}{|c|}{ Indicator } & Measurement \\
\hline 1 & $\begin{array}{l}\text { Buying } \\
\text { decision }\end{array}$ & $\begin{array}{l}\text { Buying decision is to define } \\
\text { a decision as choosing an } \\
\text { action from two or more } \\
\text { alternative choices. } \\
\text { According to Sciffman and } \\
\text { Kanuk in Sangadji and } \\
\text { Sopiah (2013: 120). }\end{array}$ & $\begin{array}{l}\text { Purpose in buying a } \\
\text { product } \\
\text { Information processing to } \\
\text { get to the brand selection } \\
\text { Stability on a product } \\
\text { Give recommendations to } \\
\text { others }\end{array}$ & Likert scale \\
\hline 2 & $\begin{array}{c}\text { Product } \\
\text { Specificatio } \\
\mathrm{n}\end{array}$ & $\begin{array}{l}\text { Product specifications are } \\
\text { based on aspects of product } \\
\text { durability or based on their } \\
\text { uses. According to Kotler } \\
\text { and Keller (2016: 391). }\end{array}$ & $\begin{array}{l}\text { Appearance } \\
\text { Appetite } \\
\text { Flavor } \\
\text { Texture }\end{array}$ & Likert scale \\
\hline 3 & Price & $\begin{array}{l}\text { Price is defined as the } \\
\text { amount of money charged } \\
\text { for an item or service or the } \\
\text { sum of the value of money } \\
\text { exchanged by consumers for } \\
\text { the benefits of owning or } \\
\text { using the product or service. } \\
\text { According to Kotler and } \\
\text { Armstrong (2013:151). }\end{array}$ & $\begin{array}{l}\text { Price tiers } \\
\text { Price affordability. } \\
\text { Price match with product } \\
\text { quality } \\
\text { Price match with } \\
\text { production benefits }\end{array}$ & Likert scale \\
\end{tabular}

\subsection{Data Analysis Techniques}

This study analyzes the data using multiple linear regression method using SPSS 20 statistical software. The models tested are:

$$
\mathrm{Y}=+\mathrm{b} 1 \mathrm{X} 1+\mathrm{b} 2 \mathrm{X} 2+
$$

Where :

$$
\begin{array}{ll}
\mathrm{Y} & =\text { Purchase decision } \\
\mathrm{X} 1 & =\text { Product } \\
\mathrm{X} 2 & =\text { Price } \\
\mathrm{A} & =\text { Constant } \\
\mathrm{b} 1,2 & =\text { regression coefficient } \\
\mathrm{e} & =\text { error or remainder }
\end{array}
$$

\subsection{Classical Assumption Test}

Classical assumption test in this study includes normality test, multicollinearity test, and heteroscedasticity test. The normality test of the graph method uses a normal probability plot, while the statistical method normality test uses the one sample Kolmogorov Smirnov Test. Multicollinearity was detected using tolerance values and Variance inflation factor (VIF). This 


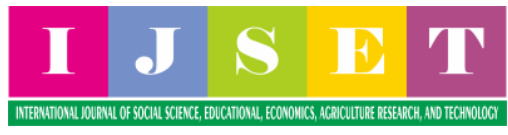

study detects the presence of heteroscedasticity by looking at the graph plot between the predicted value of the dependent variable (ZPRED) and the residual (SRESID).

\section{RESULTS AND DISCUSSION}

\subsection{Classical Assumption Test}

\subsubsection{Normality Test}

The results of the normality test can be seen in table 2 below:

Table 2 One Sample Kolmogorov Smirnov Test One-Sample Kolmogorov-Smirnov Test

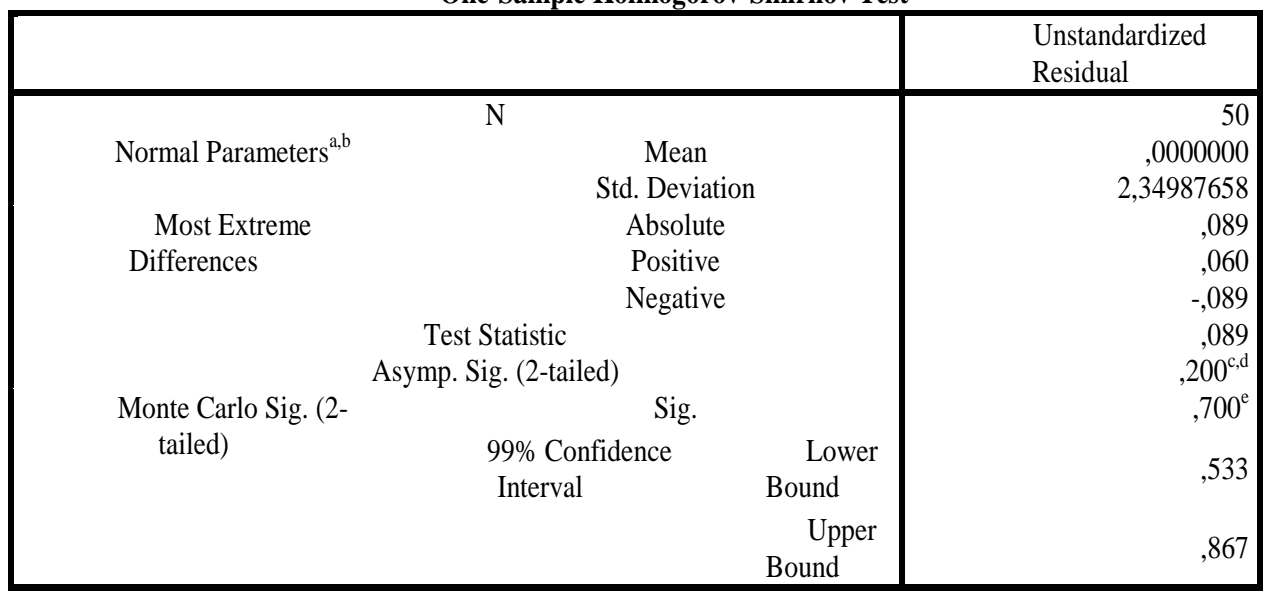

a. Test distribution is Normal.

b. Calculated from data.

c. Lilliefors Significance Correction.

d. This is a lower bound of the true significance.

e. Based on 50 sampled tables with starting seed 2000000 .

From the output in table 1, it can be seen that the significance value (Monte Carlo Sig. Lower Bound) of all variables is 0.533 . If the significance is more than 0.05 , then the residual value is normal, so it can be concluded that all variables are normally distributed.

\subsubsection{TestMulticollinearity}

The results of the multicollinearity test can be seen in table 3 below:

Table 3 Multicollinearity Test Results

\section{Coefficientsa}

\begin{tabular}{|c|c|c|ll|}
\hline \multirow{2}{*}{ Model } & \multicolumn{3}{|c|}{ Collinearity Statistics } \\
\cline { 2 - 5 } & \multicolumn{2}{|c|}{ Tolerance } & \multicolumn{1}{c|}{ VIF } \\
\hline 1 & (Constant) & & \\
& X1 &, 705 & & 1.418 \\
& X2 &, 705 & 1.418 \\
\hline
\end{tabular}

a. Dependent Variable: $\mathrm{Y}$

Based on table 3, it can be seen that the tolerance value of all independent variables is greater than 0.10 and the VIF value of all independent variables is also smaller than 5 so that there is no correlation symptom in the independent variables. So it can be concluded that there is no symptom of multicollinearity between independent variables in the regression model. 
INFLUENCE OF PRODUCT SPECIFICATIONS AND PRICES ON THE LAPTOP PURCHASE DECISION HEWLETT PACKARD (HP) BRAND

(Case Study on Pegasus Computer Store Customers Tebing Tinggi)

DOI: https://doi.org/10.54443/ijset.v1i3.16

\subsubsection{TestHeteroscedasticity}

The results of the heteroscedasticity test can be seen in Figure 2 below:

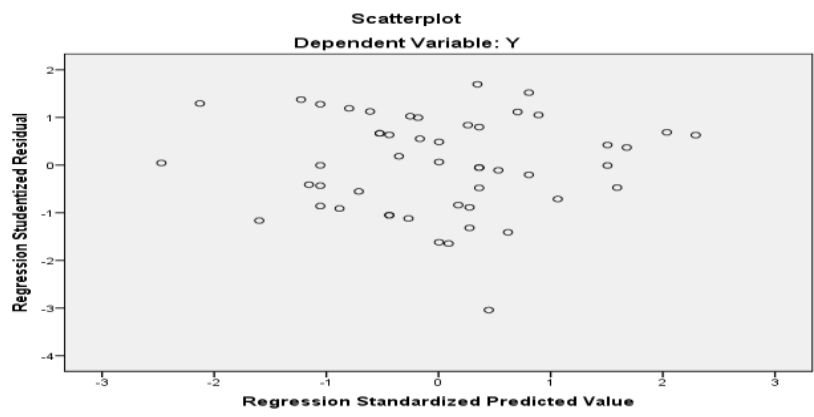

Figure 2 Scatterplot

Based on Figure 4, it can be seen that if the data pattern is perfectly distributed, some are above the zero point and some are spread below the zero point. Because of this, it can be concluded that there are no symptoms of heteroscedasticity in the regression model.

\subsection{Hypothesis Testing}

\subsubsection{TestCoefficient of Determination}

The results of the coefficient of determination test can be seen in table 4 below:

Table 4 Coefficient of Determination

Model Summary

\begin{tabular}{|c|c|c|c|c|c|c|c|c|c|}
\hline \multirow[b]{2}{*}{ Model } & \multirow[b]{2}{*}{$\mathrm{R}$} & \multirow[b]{2}{*}{$\begin{array}{l}\mathrm{R} \\
\text { Square }\end{array}$} & \multirow[b]{2}{*}{$\begin{array}{l}\text { Adjusted } \\
\text { R Square }\end{array}$} & \multirow{2}{*}{$\begin{array}{l}\text { Std. Error } \\
\text { of the } \\
\text { Estimate }\end{array}$} & \multicolumn{5}{|c|}{ Change Statistics } \\
\hline & & & & & $\begin{array}{l}\mathrm{R} \text { Square } \\
\text { Change }\end{array}$ & \begin{tabular}{|l|} 
F \\
Change
\end{tabular} & df1 & df2 & $\begin{array}{l}\text { Sig. F } \\
\text { Change }\end{array}$ \\
\hline 1 &, $317^{\mathrm{a}}$ & , 100 & ,062 & 2,39935 &, 100 & 2,618 & 2 & 47 & ,084 \\
\hline
\end{tabular}

a. Predictors: (Constant), X2, X1

b. Dependent Variable: $\mathrm{Y}$

Based on table 3, it can be seen that the adjusted $\mathrm{R}$ square value is 0.062 or $6.2 \%$. This shows that the Product Specification Variable (X1) and Price Variable (X2) can explain the Buyer's Decision Variable $(\mathrm{Y})$ of $6.2 \%$, the remaining $93.8 \%(100 \%-6.2 \%)$ is explained by other variables in outside of this research model.

\subsubsection{Test $F$ stats}

The results of the F statistical test can be seen in table 5 below:

Table 5 Simultaneous Test Results (F)

\begin{tabular}{|cc|c|c|c|c|c|}
\hline & & ANOVA & & \\
& Model & Sum of & & & & \\
\hline 1 & Squares & Df & Mean Square & F & Sig. \\
\hline & Regression & 30,146 & 2 & 15,073 & 2,618 &, $084^{\text {b }}$ \\
& Residual & 270,574 & 47 & 5,757 & & \\
& Total & 300,720 & 49 & & & \\
\hline
\end{tabular}

a. Dependent Variable: Y 
From table 4, the Fcount value is 2.618 With $=5 \%$, dk numerator: 2 , dk denominator: nk-1 (5\%; $50-2-1)$ obtained Ftable value of 3.195 From this description it can be seen that Fcount $(2.618)<$ Ftable (3.195) and a significance value of $0.084>0.05$, it can be concluded that the third hypothesis is rejected, meaning that the Product Specification Variable (X1) and Price Variable (X2) have no effect simultaneously (simultaneously) on the Buyer's Decision Variable (Y) .

\subsubsection{Test t statistics}

Regression equation:

$$
\mathrm{Y}=\mathbf{1 0 . 2 7 7}+\mathbf{0 . 4 1 5 X 1}-\mathbf{0 . 6 7 X 2}
$$

The results of the t-test can be seen in table 6 below:

Table 6 Partial Test (t)

Coefficients $^{\mathrm{a}}$

\begin{tabular}{|c|c|c|c|c|c|}
\hline \multirow{2}{*}{ Model } & \multicolumn{2}{|c|}{} & & \\
\cline { 2 - 4 } & Unstandardized Coefficients & Standardized Coefficients & & \\
\cline { 2 - 4 } & $\mathrm{B}$ & Std. Error & Beta & ig. \\
(Constant) & 10,277 & 2,841 & & 3,617 & 001 \\
X1 &, 415 &, 197 &, 347 & 2,104 & 041 \\
X2 &,- 067 &, 174 &,- 064 &,- 387 & 701 \\
\hline
\end{tabular}

a. Dependent Variable: $\mathrm{Y}$

From table 6 , the tcount value is $2.104 \mathrm{With}=5 \%$, table $(5 \%$; $\mathrm{nk}=50-2=48)$ the table value is 1.677. From the description it can be seen that tcount (2.104) > ttable (1.677), as well as with a significance value of $0.041<0.05$, it can be concluded that the first hypothesis is accepted, meaning that the product specification variable (X1) affects the buyer's decision variable (Y).

From table 5, the tcount value is -0.387 . With $=5 \%$, ttable $(5 \% ; \mathrm{nk}=50-2=48)$ the ttable value is -1.677 . From the description it can be seen that tcount $(-0.387)>$ ttable $(-1.677)$, and the significance value is $0.701>0.05$, it can be concluded that the second hypothesis is accepted, meaning that the price variable (X2) affects the buyer's decision variable $(\mathrm{Y})$, but significantly this hypothesis does not affect the Purchase Decision (Y).

\section{CONCLUSIONS AND SUGGESTIONS}

\subsection{Conclusion}

From the results of research on the effect of product specifications and prices on purchasing decisions of Hewlett Packard brand laptops (Case Study on Pegasus Computer Store Customers Tebing Tinggi). So it can be concluded as follows:

1. The product specification variable (X1) has an effect on the buyer's decision variable (Y).

2. The price variable (X2) has an effect on the buyer's decision variable (Y), but significantly this hypothesis has no effect on the Purchase Decision (Y).

3. The product specification variable (X1) and the price variable (X2) have no effect simultaneously (simultaneously) on the buyer's decision variable (Y).

\subsection{Suggestion}

The authors' suggestions for this research are as follows: (1) To improve the price system for purchasing Hewlett Packard brand laptops, the Pegasus Computer Tebing Tinggi shop should show various kinds of Hewlett Packard laptop prices in accordance with the benefits of the product. (2) To improve product specifications when purchasing Hewlett Packard brand laptops, the Pegasus Computer Tebing Tinggi store should train sales (salespeople) to study various specifications of Hewlett Packard products and adapt them to the tastes of the intended 
consumers. (3) To improve purchasing decisions for Hewlett Packard brand laptops, the Pegasus Computer Tebing Tinggi store should provide complete information about Hewlett Packard products to get to the brand selection.

\section{REFERENCES}

Abdullah, Thamrin and Francis Tantri. 2013. Marketing Management. cet. II. PT Raja Grafindo Perseda, Jakarta

Alma, B. 2014. Service Marketing Management. Alphabeta, Bandung

Kotler and Armstrong. 2008. Principles of Marketing. Volumes 1 and 2. Edition 12. Jakarta: Erlangga.

Mursid, M. 2014. Marketing Management Consumer Behavior Analysis. BPFE, Yogyakarta

Sangadji, Etta Mamang \& Sopiah. 2013. Consumer Behavior - A Practical Approach with the Association of Research Journals. Yogyakarta: ANDI

Schiffman, Leon and Leslie Lazar Kanuk. 2008. Consumer Behavior. PT. Index, Jakarta

Tjiptono. 2008. Marketing Strategy. Edition 3. Andi, Yogyakarta

Swastha, Basu and Irawan. 2010. Marketing Management. Liberty, Yogyakarta

Swastha, Basu. 2010. Sales Management: Sales Implementation. BPFE, Yogyakarta 